\title{
Ghrelin Cells in the Gastrointestinal Tract
}

\author{
Ichiro Sakata $^{1}$ and Takafumi Sakai ${ }^{2}$ \\ ${ }^{1}$ Divisions of Hypothalamic Research and Endocrinology \& Metabolism, Department of Internal Medicine, \\ The University of Texas Southwestern Medical Center, 5323 Harry Hines Blvd, Dallas, TX 75390-9077, USA \\ ${ }^{2}$ Area of Regulatory Biology, Division of Life Science, Graduate School of Science and Engineering, Saitama University, \\ Saitama 338-8570, Japan
}

Correspondence should be addressed to Takafumi Sakai, tsakai@mail.saitama-u.ac.jp

Received 16 October 2009; Accepted 11 January 2010

Academic Editor: Akio Inui

Copyright (C) 2010 I. Sakata and T. Sakai. This is an open access article distributed under the Creative Commons Attribution License, which permits unrestricted use, distribution, and reproduction in any medium, provided the original work is properly cited.

\begin{abstract}
Ghrelin is 28-amino-acid peptide that was discovered from the rat and human stomach in 1999. Since the discovery of ghrelin, various functions of ghrelin, including growth hormone release, feeding behavior, glucose metabolism, memory, and also antidepressant effects, have been studied. It has also been reported that ghrelin in the gastrointestinal tract has an important physiological effect on gastric acid secretion and gastrointestinal motility. Ghrelin has a unique structure that is modified by $O$ acylation with n-octanoic acid at third serine residues, and this modification enzyme has recently been identified and named ghrelin $\mathrm{O}$-acyl transferase (GOAT). Ghrelin is considered to be a gut-brain peptide and is abundantly produced from endocrine cells in the gastrointestinal mucosa. In the gastrointestinal tract, ghrelin cells are most abundant in the stomach and are localized in gastric mucosal layers. Ghrelin cells are also widely distributed throughout the gastrointestinal tract. In addition, abundance of ghrelin cells in the gastric mucosa is evolutionally conserved from mammals to lower vertebrates, indicating that gastric ghrelin plays important roles for fundamental physiological functions. Ghrelin cells in the gastrointestinal tract are a major source of circulating plasma ghrelin, and thus understanding the physiology of these cells would reveal the biological significance of ghrelin.
\end{abstract}

\section{Introduction}

Several distinct types of endocrine cells, including histamineproducing ECL cells, somatostatin-producing D cells, gastrin-producing $G$ cells, and serotonin-producing EC cells, have been shown to be present in the mammalian stomach. Before the discovery of ghrelin, gastric ghrelin cells were classified as unknown endocrine cells by their round, compact, electron-dense secretory granules $(\mathrm{P} / \mathrm{D}(1)$ type in humans, A-like-type in rodents, and X-type in dogs) that distinguish them electron-microscopically from other previously characterized gastric endocrine cell types $[1,2]$. Ghrelin was identified as an endogenous ligand for growth hormone secretagogue receptor (GHS-R) from the stomach in 1999 [3]. Ghrelin structurally resembles motilin and they share about $21 \%$ amino acid identity and their receptor also has structural similarity with $44 \%$ similarity in amino acids, indicating that they comprise a motilin-ghrelin family $[4,5]$. Interestingly, ghrelin was found to be present as two molecular forms: acyl-ghrelin modified with medium chain fatty acids and des-acylated-ghrelin lacking side chain modification $[3,6]$. Although acyl-ghrelin is only known to bind to GHS-R [7], accumulating results have shown that des-acylated-ghrelin has various physiological functions via unknown specific receptor, including involvement in cell death, feeding behavior, and energy and glucose homeostasis [8-13]. Moreover, in 2005, obestatin was identified as a peptide hormone derived from preproghrelin in the stomach [14] and obestatin has been shown to be involved in energy homeostasis, gastrointestinal motility, memory, sleep, and cell proliferation [13-18].

In this review, we focus on ghrelin cells in the gastrointestinal tract and describe the characteristic features, development, and regulation of ghrelin cells.

\section{Distribution and Morphological Features of Ghrelin Cells in the Gastrointestinal Tract}

The distribution of ghrelin-producing cells in the gastrointestinal tract has been studied by using immunohistochemical techniques and in situ hybridization $[1,2,19,20]$. 


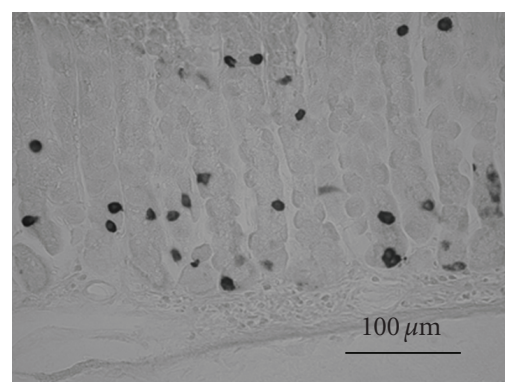

(a)

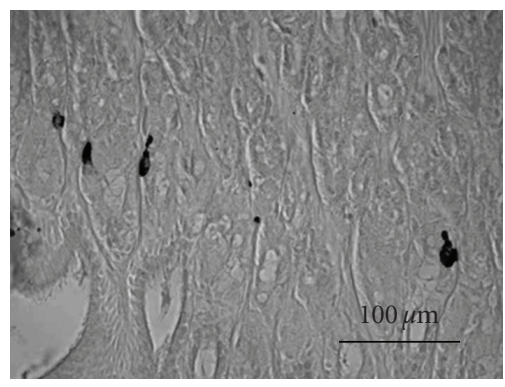

(c)

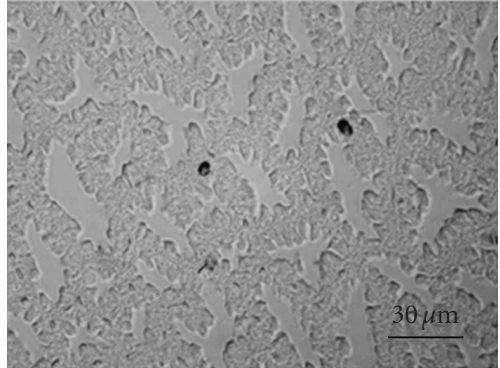

(b)

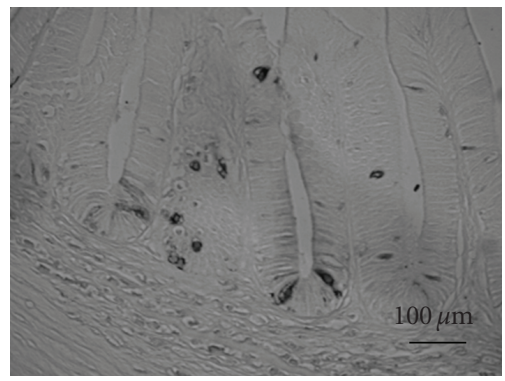

(d)

FIGURE 1: Localization of ghrelin-immunopositive cells in the stomach (rodents, avians, amphibians and fish). (a) Ghrelin cells in the rat stomach. Ghrelin cells are mainly observed from the glandular base to the body of the fundic gland, and gastric ghrelin cells in the rat have been clarified to be closed-type cells. Ghrelin cells are scattered throughout the mucosal layer in (b) the proventriculus of the chicken and (c) bullfrog stomach, and those ghrelin cells are also closed-type cells as rodents. (d) Ghrelin cells in the trout stomach are localized in the mucosal layer, and both closed- and opened-type cells are found in the trout. Scale bars $=100 \mu \mathrm{m}$ in (a), (c), (d); $30 \mu \mathrm{m}$ in (b).

In rodents, ghrelin-producing cells were observed in all regions of the gastrointestinal tract: gastric body, antrum, duodenum, ileum, cecum, and colon. Ghrelin-producing cells were most dense in the gastric body (Figure 1(a)) and were found in the mucosal layer but not in the myenteric plexus in all of the examined regions. In the stomach, most of the ghrelin cells were observed in the glandular base decreasing in amount as the gland extends toward the lumen with a few cells observed in the glandular neck. In the duodenum, ileum, cecum, and colon, ghrelin cells were scattered in the epithelia of crypts and villi. The densities of ghrelin cells were dramatically decreased toward the lower gastrointestinal tract [19]. The number of ghrelin-producing cells in each gastrointestinal tract corresponded well with the amount of peptide and mRNA expression levels [21]. In addition, plasma concentration of ghrelin in rats was decreased by $80 \%$ after gastrectomy [1], and also plasma ghrelin levels were reduced by $65 \%$ in human gastrectomised patients, strongly suggesting that major source of circulating plasma ghrelin is the gastric mucosa [22].

The morphological features of ghrelin-producing cells in the stomach differ from those of the intestinal tracts. In the stomach, ghrelin-producing cells were found to be small and round-shaped, so-called closed-type cells [1, 19, 23]. However, in the duodenum, ileum, cecum, and colon, two types of ghrelin cells were found; that is, closed-type cells with triangular or elongated shapes and opened-type cells with their apical cytoplasmic process contacting to the lumen. In general, opened-type cells are functionally regulated by receiving luminal information such as nutrients and $\mathrm{pH}$, while closed-type cells are functionally modulated by hormones, neuronal stimulation, or mechanical distension [24]. Thus, the regulatory mechanisms of ghrelin release would be different in the stomach and other parts of the gastrointestinal tract. By electron microscopic observation, several groups have shown that immunogold labeling for ghrelin was localized on the round and electron-dense granules in gastric mucosal cells [2, 25-27]. Yabuki et al. showed that the diameters of granules containing ghrelin in mice $(277.7 \pm 11.1 \mathrm{~nm})$ and rats $(268.8 \pm 13.0 \mathrm{~nm})$ were similar; however, those in hamsters $(200.8 \pm 8.8 \mathrm{~nm})$ were significantly smaller than those in mice or rats [26]. Rindi et al. demonstrated that mouse and canine ghrelinimmunoreactive cells closely resembled those of the human stomach, though it has been shown that dog ghrelin cells have obviously larger granules (mean diameter of $273 \pm$ $49 \mathrm{~nm}$ ) than those of rats (mean diameter of $183 \pm 37 \mathrm{~nm}$ ) and humans $(147 \pm 30 \mathrm{~nm})$ [27].

Localization of GOAT (Ghrelin O-Acyltransferase) and ghrelin was also recently studied by using in situ hybridization histochemistry and immunohistochemistry, and a high degree of colocalization of GOAT and ghrelin was observed in mouse gastric oxyntic mucosal cells [28]. On the other hand, ghrelin-GFP transgenic mice expressing humanized Renilla reniformis green fluorescent protein (hrGFP) under control of the mouse ghrelin promoter has recently been 
generated and it has been confirmed that hrGFP expression was especially abundant in the gastric oxyntic mucosa, in a pattern mirroring that of ghrelin immunoreactivity and ghrelin mRNA [28].

\section{Relationship of Ghrelin and Motilin Cells}

Motilin was originally isolated from porcine intestinal mucosa in the 1970s [29, 30]. Motilin is 22-amino-acid peptide and it is known to play an important role for the interdigestive migrating motor complex (MMC) [31]. Ghrelin and motilin and their receptors have similar structures and these two peptides are known to form a motilinghrelin peptide family $[5,32]$. It has been demonstrated that ghrelin stimulates gastrointestinal motility in rodents, suggesting that a part of the physiological effects of these two peptides is also overlapped. The distributions of ghrelin and motilin cells are separated; motilin is mainly produced in the upper intestine, but ghrelin cells are localized mainly in the stomach. Recently, Wierup et al. demonstrated that over $90 \%$ of ghrelin cells in the porcine duodenum coexpressed motilin, and they also observed by electron microscopic immunolabeling that they were localized on the same secretory granules, indicating that they were cosecreted with the same stimulation [33]. On the other hand, sequences of ghrelin and motilin in the house musk shrew were determined, and no coexistence of ghrelin and motilin was found in gastric and duodenal cells [34, 35]. Therefore, further studies are needed to elucidate the coexistence of ghrelin and motilin in one cell by using other animal models.

\section{Development of Ghrelin Cells in the Gastrointestinal Tract}

Ghrelin was found to be expressed in the fetal stomach from embryonic day 18 and the number of fetal gastric ghrelin cells increased as the stomach grew, with gastric ghrelin content also increasing with advance of age [36]. Detailed study showed that ghrelin-immunopositive cells appeared in the glandular base of the fundic gland at 1 week of age and they were found in the glandular base and the glandular neck at 3 weeks of age. Then the distribution of ghrelin cells was extended from the glandular base to the glandular neck during the postneonatal developmental period [37]. Walia et al. have also reported that ghrelin-immunoreactive cells were rare at embryonic day 21 and that their number increased progressively until weaning [38]. Gastric ghrelin mRNA levels also increased in an age-dependent manner similar to the number of ghrelin cells $[36,37,39]$. In addition, ghrelin cells in female rats differentiated at an earlier stage of development than that in male rats, and the density of ghrelin cells in female rats was also higher than that in male rats [37]. In humans, plasma ghrelin level was also higher in females than in males [40].

\section{Distribution and Features of Ghrelin Cells in Nonmammalian Vertebrates}

Ghrelin has been characterized not only in mammals but also, many other species, avians, amphibians, reptiles, and fish, and it has been shown that the structures of ghrelin peptide were well preserved from mammals to lower vertebrates [41]. The N-terminal regions of the first seven amino acids in lower vertebrates were well conserved, and the third serine or threonine residue is modified with medium chain fatty acid, mainly octanoic acid, as in mammals [41]. In nonmammalians, it has been confirmed that ghrelin mRNA is abundantly expressed in the stomach [42-48]. In avians, ghrelin-immunopositive cells were found in the mucosal layer of the proventriculus (Figure 1(b)) that corresponds to a first glandular part of the stomach in which digestive enzymes are mixed with food before the gizzard [49]. However, ghrelin immunoreactivity in avians was not located in the myenteric plexus, and many more ghrelinimmunopositive cells were found in the middle layer than in the base of the mucosal layer, with the majority of ghrelin cells being round-shaped and closed-type cells [49]. Features of gastric ghrelin cells in amphibians and reptiles are similar to mammals or avian ghrelin cells. Ghrelin cells in these animals were also found in the gastric mucosal layer but not in the myenteric plexus or muscle layers of the stomach, and the ghrelin cells are closed-type cells in frogs (Figure 1(c)) and turtles $[45,50]$. Ghrelin cells in rainbow trout were found to be localized as closed-type cells and opened-type cells in the gastric mucosa (Figure 1(d)) [51].

\section{Regulation of Ghrelin Cells in the Gastrointestinal Tract}

6.1. Ghrelin Cells on Fasting. Ghrelin is a potent orexigenic peptide that stimulates food intake and body weight gain, suggesting that ghrelin plays an important role in energy homeostasis. Numerous data have shown that plasma ghrelin levels were elevated in a fasting state and returned to basal levels after refeeding $[32,52,53]$. On the other hand, peptide content of ghrelin in the stomach decreased after fasting [54], indicating that cytoplasmic ghrelin released from gastric ghrelin cells caused an increase in plasma ghrelin levels. Compared to biochemical analysis, studies on changes in the number and staining property of gastric ghrelin cells in a fasting state are quite restricted. For example, the number of ghrelin-immunopositive cells significantly increased in rats during fasting for 7 days, and then the cell number decreased to a normal level after refeeding [55]. In bullfrogs, no significant differences in numbers of ghrelin cells were observed during fasting for 20 days [50]. Moreover, in fish fasted for 72 hours, Govoni et al. found no clear differences in ghrelin cell numbers and their immunostaining intensity $[18,30,56]$. Therefore, further studies are needed to elucidate the number of ghrelin cells in a multiple time point study during a fasting period.

6.2. Ghrelin and Nutrients. As mentioned above, ghrelin is known to be a hunger signal from peripheral tissues, and plasma ghrelin levels drop to basal levels after a meal, suggesting that ghrelin cells are regulated by nutrient uptake. It has been reported that oral and intravenous glucose administration sharply reduced plasma ghrelin concentration in rodents $[53,57]$, and this effect of glucose on ghrelin 
inhibition was similar to that found in human studies [5861]. Williams et al. studied the effect of intragastric load of glucose on plasma ghrelin levels, and they found that plasma ghrelin level was reduced by approximately $50 \%$ under a normal gastric emptying condition [62]. On the other hand, plasma ghrelin levels were not changed in pyloric cuffimplanted rats, indicating that ghrelin release from gastric ghrelin cells is affected by glucose that is absorbed from the intestine [62]. In addition to glucose, duodenal and jejunal infusions of lipids or amino acids reduced ghrelin levels in rats [63]. These effects have been confirmed in human studies; free fatty acids or protein administration decreased plasma ghrelin levels $[64,65]$. However, the mechanisms by which these nutrients regulate on gastric ghrelin release in the stomach remain unclear. Further studies are needed to elucidate the molecular pathway of ghrelin cell regulation by nutrients.

6.3. Hormonal Control of Gastric Ghrelin. Ghrelin is also regulated by circulating and gastric hormones. Ghrelin cells are located close to somatostatin-producing D cells [66], and somatostatin inhibits ghrelin secretion in rats and humans [66-69]. Intravenous administration of glucagon caused transient increases in both acyl- and des acyl-ghrelin levels. Moreover, ghrelin secretion from the perfused stomach was stimulated by glucagon treatment in a dose-dependent manner [70], and this effect was shown to be mediated by glucagon receptors on ghrelin cells [71]. de la Cour et al. performed a microdialysis study to find a possible ghrelin regulator in the stomach, and they found that epinephrine, norepinephrine, endothelin, and secretin stimulated ghrelin release [69].

Steroid hormone is also involved in ghrelin regulation. A role of estrogen in the regulation of gastric ghrelin has also been suggested by several studies. In humans, estrogen regulates plasma ghrelin concentration [72-75]. The levels of gastric ghrelin mRNA and plasma ghrelin and the number of ghrelin cells were found to be transiently increased by ovariectomy in female rats [76]. Treatment of gastric mucosal cells with estrogen showed that estrogen stimulated ghrelin expression and ghrelin secretion [77, 78]. These findings indicate that gastric estrogen plays an important role in the regulation of gastric ghrelin at the transcriptional level.

\section{Ghrelin Cells in the Digestive Diseases}

In addition to the physiological, biochemical, and structural studies of ghrelin, pathological aspects of ghrelin have been studied in various diseases, such as anorexia nervosa, Prader Willi Syndrome (PWS), Polycystic Syndrome (PCOS), and Celiac Disease (CD) [79-84]. The role of ghrelin in Helicobacter pylori (H. pylori) infections, gastric diseases such as chronic gastritis, gastric and duodenal ulcers, and gastric carcinomas, has been widely studied. While there are conflicting results, many papers have shown that plasma ghrelin concentrations in the $\mathrm{H}$. pylori positive subjects were lower than in $\mathrm{H}$. pylori negative subjects [85-87]. When correlated with the plasma ghrelin levels, the number of ghrelin immunopositive cells was significantly lower in $\mathrm{H}$. pylori positive subjects than in negative subjects $[85,88]$. Furthermore, ghrelin mRNA expression levels were also lower in $\mathrm{H}$. pylori-infected human subjects [88]. Using Mongolian gerbils as an animal model of $\mathrm{H}$. pylori infection, Suzuki et al. showed that ghrelin mRNA expression levels were significantly lower in animals with $\mathrm{H}$. pylori, compared to control animals [89]. Furthermore, the number of ghrelin immunopositive cells decreased in H. pylori-infected groups 17 and 23 weeks after infection, while the total number of gastric mucosal cells remained unchanged. In addition, when compared to control animals, gastric ghrelin contents were significantly decreased in infected animals 17 and 23 weeks after $\mathrm{H}$. pylori inoculation, although no differences were detected after only four weeks. Notably, ghrelin cells in the gastric mucosa are located close to the parietal cells, and some of these cells are found to be in contact with each other $[77,89]$, and it has been reported that $\mathrm{H}$. pylori affected the function of parietal cells $[90,91]$. Although further studies are needed to elucidate the biological mechanisms behind the regulation of gastric ghrelin after $\mathrm{H}$. pylori infection, it is possible that gastric estrogen, which is produced in parietal cells, could affect ghrelin cells in a paracrine manner. Alternatively, inflammatory factors may act directly on ghrelin cells to decrease their activity.

\section{Conclusions}

Ghrelin is predominantly produced in the stomach, and gastric ghrelin is thought to play important multiple physiological roles in peripheral signaling. Results of the analysis of ghrelin cells in the gastrointestinal tract have been accumulating. Many factors including nutrients as well as circulating and gastric hormones were found to be involved in the regulation of mRNA and release of ghrelin, indicating that ghrelin cells are under the control of complicated mechanisms, which are still obscure. In addition, characteristics of ghrelin cells in the stomach and other parts of the gastrointestinal tract are different; closedtype ghrelin cells are localized in the stomach and many opened-type ghrelin cells are localized throughout the small and large intestines. Since the length of the gastrointestinal tract is long, considerable amounts of plasma ghrelin can be assumed to be derived from ghrelin cells in small and large intestines. Further studies are needed to understand the physiological and pathological roles of ghrelin cells in both small and large intestines. Moreover, posttranscriptional modifications are very important for physiological active ghrelin, necessitating the need to understand how GOAT is involved in the regulation of ghrelin biosynthesis and consequently may be important for controlling ghrelin cells in some physiological states.

\section{Acknowledgment}

This work was supported in part by Grant-in-Aid for the Scientific Research C from the Ministry of Education, Culture, Sports, Science and Technology (MEXT). 


\section{References}

[1] C. Dornonville de la Cour, M. Björkqvist, A. K. Sandvik, et al., "A-like cells in the rat stomach contain ghrelin and do not operate under gastrin control," Regulatory Peptides, vol. 99, no. 2-3, pp. 141-150, 2001.

[2] Y. Date, M. Kojima, H. Hosoda, et al., "Ghrelin, a novel growth hormone-releasing acylated peptide, is synthesized in a distinct endocrine cell type in the gastrointestinal tracts of rats and humans," Endocrinology, vol. 141, no. 11, pp. 42554261, 2000.

[3] M. Kojima, H. Hosoda, Y. Date, M. Nakazato, H. Matsuo, and K. Kangawa, "Ghrelin is a growth-hormone-releasing acylated peptide from stomach," Nature, vol. 402, no. 6762, pp. 656660, 1999.

[4] B. De Smet, A. Mitselos, and I. Depoortere, "Motilin and ghrelin as prokinetic drug targets," Pharmacology and Therapeutics, vol. 123, no. 2, pp. 207-223, 2009.

[5] C. Folwaczny, J. K. Chang, and M. Tschop, "Ghrelin and motilin: two sides of one coin?" European Journal of Endocrinology, vol. 144, no. 4, pp. R1-R3, 2001.

[6] H. Hosoda, M. Kojima, H. Matsuo, and K. Kangawa, "Ghrelin and des-acyl ghrelin: two major forms of rat ghrelin peptide in gastrointestinal tissue," Biochemical and Biophysical Research Communications, vol. 279, no. 3, pp. 909-913, 2000.

[7] H. D. Falls, B. D. Dayton, D. G. Fry, et al., "Characterization of ghrelin receptor activity in a rat pituitary cell line RC-4B/C," Journal of Molecular Endocrinology, vol. 37, no. 1, pp. 51-62, 2006.

[8] G. Baldanzi, N. Filigheddu, S. Cutrupi, et al., "Ghrelin and des-acyl ghrelin inhibit cell death in cardiomyocytes and endothelial cells through ERK1/2 and PI 3-kinase/AKT," Journal of Cell Biology, vol. 159, no. 6, pp. 1029-1037, 2002.

[9] C.-Y. Chen, A. Inui, A. Asakawa, et al., "Des-acyl ghrelin acts by CRF type 2 receptors to disrupt fasted stomach motility in conscious rats," Gastroenterology, vol. 129, no. 1, pp. 8-25, 2005.

[10] W. Zhang, B. Chai, J.-Y. Li, H. Wang, and M. W. Mulholland, "Effect of des-acyl ghrelin on adiposity and glucose metabolism," Endocrinology, vol. 149, no. 9, pp. 4710-4716, 2008.

[11] K. Toshinai, H. Yamaguchi, Y. Sun, et al., "Des-acyl ghrelin induces food intake by a mechanism independent of the growth hormone secretagogue receptor," Endocrinology, vol. 147, no. 5, pp. 2306-2314, 2006.

[12] J.-B. Soares and A. F. Leite-Moreira, "Ghrelin, des-acyl ghrelin and obestatin: three pieces of the same puzzle," Peptides, vol. 29, no. 7, pp. 1255-1270, 2008.

[13] M. Fujimiya, A. Asakawa, K. Ataka, I. Kato, and A. Inui, "Different effects of ghrelin, des-acyl ghrelin and obestatin on gastroduodenal motility in conscious rats," World Journal of Gastroenterology, vol. 14, no. 41, pp. 6318-6326, 2008.

[14] J. V. Zhang, P.-G. Ren, O. Avsian-Kretchmer, et al., "Obestatin, a Peptide Encoded by the Ghrelin Gene, Opposes Ghrelin's Effects on Food Intake," Science, vol. 310, no. 5750, pp. 996999, 2005.

[15] R. Nogueiras, P. Pfluger, S. Tovar, et al., "Effects of obestatin on energy balance and growth hormone secretion in rodents," Endocrinology, vol. 148, no. 1, pp. 21-26, 2007.

[16] S.-Q. Tang, Q.-Y. Jiang, Y.-L. Zhang, et al., "Obestatin: its physicochemical characteristics and physiological functions," Peptides, vol. 29, no. 4, pp. 639-645, 2008.

[17] B. Bodosi, J. Gardi, I. Hajdu, E. Szentirmai, F. Obal Jr., and J. M. Krueger, "Rhythms of ghrelin, leptin, and sleep in rats: effects of the normal diurnal cycle, restricted feeding, and sleep deprivation," American Journal of Physiology, vol. 287, no. 5, pp. R1071-R1079, 2004.

[18] V. P. Carlini, H. B. Schiöth, and S. R. Debarioglio, "Obestatin improves memory performance and causes anxiolytic effects in rats," Biochemical and Biophysical Research Communications, vol. 352, no. 4, pp. 907-912, 2007.

[19] I. Sakata, K. Nakamura, M. Yamazaki, et al., "Ghrelinproducing cells exist as two types of cells, closed- and openedtype cells, in the rat gastrointestinal tract," Peptides, vol. 23, no. 3, pp. 531-536, 2002.

[20] M. Grönberg, A. V. Tsolakis, L. Magnusson, E. T. Janson, and J. Saras, "Distribution of obestatin and ghrelin in human tissues: immunoreactive cells in the gastrointestinal tract, pancreas, and mammary glands," Journal of Histochemistry and Cytochemistry, vol. 56, no. 9, pp. 793-801, 2008.

[21] H. M. Lee, G. Wang, E. W. Englander, M. Kojima, and G. H. Greeley Jr., "Ghrelin, a new gastrointestinal endocrine peptide that stimulates insulin secretion: enteric distribution, ontogeny, influence of endocrine, and dietary manipulations," Endocrinology, vol. 143, no. 1, pp. 185-190, 2002.

[22] H. Ariyasu, K. Takaya, T. Tagami, et al., "Stomach is a major source of circulating ghrelin, and feeding state determines plasma ghrelin-like immunoreactivity levels in humans," Journal of Clinical Endocrinology and Metabolism, vol. 86, no. 10, pp. 4753-4758, 2001.

[23] C.-M. Zhao, M. W. Furnes, B. Stenström, B. Kulseng, and D. Chen, "Characterization of obestatin- and ghrelin-producing cells in the gastrointestinal tract and pancreas of rats: an immunohistochemical and electron-microscopic study," Cell and Tissue Research, vol. 331, no. 3, pp. 575-587, 2008.

[24] W. Y. Lew and M. M. LeWinter, "Regional comparison of midwall segment and area shortening in the canine left ventricle," Circulation Research, vol. 58, no. 5, pp. 678-691, 1986.

[25] C. Tomasetto, S. M. Karam, S. Ribieras, et al., "Identification and characterization of a novel gastric peptide hormone: the motilin-related peptide," Gastroenterology, vol. 119, no. 2, pp. 395-405, 2000.

[26] A. Yabuki, T. Ojima, M. Kojima, et al., "Characterization and species differences in gastric ghrelin cells from mice, rats and hamsters," Journal of Anatomy, vol. 205, no. 3, pp. 239-246, 2004.

[27] G. Rindi, A. Savio, A. Torsello, et al., "Ghrelin expression in gut endocrine growths," Histochemistry and Cell Biology, vol. 117, no. 6, pp. 521-525, 2002.

[28] I. Sakata, J. Yang, C. E. Lee, et al., "Colocalization of ghrelin Oacyltransferase and ghrelin in gastric mucosal cells," American Journal of Physiology, vol. 297, no. 1, pp. E134-E141, 2009.

[29] J. C. Brown, M. A. Cook, and J. R. Dryburgh, "Motilin, a gastric motor activity stimulating polypeptide: the complete amino acid sequence," Canadian Journal of Biochemistry, vol. 51, no. 5, pp. 533-537, 1973.

[30] J. C. Brown and J. R. Dryburgh, "Discovery of motilin," Scandinavian Journal of Gastroenterology, vol. 39, pp. 15-17, 1976.

[31] Z. Itoh, S. Takeuchi, I. Aizawa, et al., "Changes in plasma motilin concentration and gastrointestinal contractile activity in conscious dogs," American Journal of Digestive Diseases, vol. 23, no. 10, pp. 929-935, 1978.

[32] A. Asakawa, A. Inui, T. Kaga, et al., "Ghrelin is an appetitestimulatory signal from stomach with structural resemblance to motilin," Gastroenterology, vol. 120, no. 2, pp. 337-345, 2001. 
[33] N. Wierup, M. Björkqvist, B. Westrom, S. Pierzynowski, F. Sundler, and K. Sjolund, "Ghrelin and motilin are cosecreted from a prominent endocrine cell population in the small intestine," Journal of Clinical Endocrinology and Metabolism, vol. 92, no. 9, pp. 3573-3581, 2007.

[34] C. Tsutsui, K. Kajihara, T. Yanaka, et al., "House musk shrew (Suncus murinus, order: Insectivora) as a new model animal for motilin study," Peptides, vol. 30, no. 2, pp. 318-329, 2009.

[35] Y. Ishida, S. Sakahara, C. Tsutsui, et al., "Identification of ghrelin in the house musk shrew (Suncus murinus): cDNA cloning, peptide purification and tissue distribution," Peptides, vol. 30, no. 5, pp. 982-990, 2009.

[36] T. Hayashida, K. Nakahara, M. S. Mondal, et al., "Ghrelin in neonatal rats: distribution in stomach and its possible role," Journal of Endocrinology, vol. 173, no. 2, pp. 239-245, 2002.

[37] I. Sakata, T. Tanaka, M. Matsubara, et al., "Postnatal changes in ghrelin mRNA expression and in ghrelin-producing cells in the rat stomach," Journal of Endocrinology, vol. 174, no. 3, pp. 463-471, 2002.

[38] P. Walia, A. Asadi, T. J. Kieffer, J. D. Johnson, and J.-P. Chanoine, "Ontogeny of ghrelin, obestatin, preproghrelin, and prohormone convertases in rat pancreas and stomach," Pediatric Research, vol. 65, no. 1, pp. 39-44, 2009.

[39] O. Gualillo, J. E. Caminos, M. Kojima, et al., "Gender and gonadal influences on ghrelin mRNA levels in rat stomach," European Journal of Endocrinology, vol. 144, no. 6, pp. 687690, 2001.

[40] T. Akamizu, T. Shinomiya, T. Irako, et al., "Separate measurement of plasma levels of acylated and desacyl ghrelin in healthy subjects using a new direct ELISA assay," Journal of Clinical Endocrinology and Metabolism, vol. 90, no. 1, pp. 6-9, 2005.

[41] H. Kaiya, M. Miyazato, K. Kangawa, R. E. Peter, and S. Unniappan, "Ghrelin: a multifunctional hormone in non-mammalian vertebrates," Comparative Biochemistry and Physiology-Part A, vol. 149, no. 2, pp. 109-128, 2008.

[42] H. Kaiya, M. Kojima, H. Hosoda, et al., "Bullfrog ghrelin is modified by n-octanoic acid at its third threonine residue," Journal of Biological Chemistry, vol. 276, no. 44, pp. 4044140448, 2001.

[43] H. Kaiya, S. van der Geyten, M. Kojima, et al., "Chicken ghrelin: purification, cDNA cloning, and biological activity," Endocrinology, vol. 143, no. 9, pp. 3454-3463, 2002.

[44] H. Kaiya, M. Kojima, H. Hosoda, et al., "Identification of tilapia ghrelin and its effects on growth hormone and prolactin release in the tilapia, Oreochromis mossambicus," Comparative Biochemistry and Physiology Part B, vol. 135, no. 3, pp. 421429, 2003.

[45] H. Kaiya, I. Sakata, M. Kojima, H. Hosoda, T. Sakai, and K. Kangawa, "Structural determination and histochemical localization of ghrelin in the red-eared slider turtle, Trachemys scripta elegans," General and Comparative Endocrinology, vol. 138, no. 1, pp. 50-57, 2004.

[46] I. S. Parhar, H. Sato, and Y. Sakuma, "Ghrelin gene in cichlid fish is modulated by sex and development," Biochemical and Biophysical Research Communications, vol. 305, no. 1, pp. 169$175,2003$.

[47] G. Terova, S. Rimoldi, G. Bernardini, R. Gornati, and M. Saroglia, "Sea bass ghrelin: molecular cloning and mRNA quantification during fasting and refeeding," General and Comparative Endocrinology, vol. 155, no. 2, pp. 341-351, 2008.

[48] A. Kawakoshi, H. Kaiya, L. G. Riley, et al., "Identification of a ghrelin-like peptide in two species of shark, Sphyrna lewini and Carcharhinus melanopterus," General and Comparative Endocrinology, vol. 151, no. 3, pp. 259-268, 2007.
[49] R. Wada, I. Sakata, H. Kaiya, et al., "Existence of ghrelinimmunopositive and -expressing cells in the proventriculus of the hatching and adult chicken," Regulatory Peptides, vol. 111, no. 1-3, pp. 123-128, 2003.

[50] H. Kaiya, I. Sakata, K. Yamamoto, et al., "Identification of immunoreactive plasma and stomach ghrelin, and expression of stomach ghrelin mRNA in the bullfrog, Rana catesbeiana," General and Comparative Endocrinology, vol. 148, no. 2, pp. 236-244, 2006.

[51] I. Sakata, T. Mori, H. Kaiya, et al., "Localization of ghrelinproducing cells in the stomach of the rainbow trout (Oncorhynchus mykiss)," Zoological Science, vol. 21, no. 7, pp. 757-762, 2004.

[52] K. Toshinai, M. S. Mondal, M. Nakazato, et al., "Upregulation of ghrelin expression in the stomach upon fasting, insulininduced hypoglycemia, and leptin administration," Biochemical and Biophysical Research Communications, vol. 281, no. 5, pp. 1220-1225, 2001.

[53] M. Tschop, D. L. Smiley, and M. L. Heiman, "Ghrelin induces adiposity in rodents," Nature, vol. 407, no. 6806, pp. 908-913, 2000.

[54] T. Sato, Y. Fukue, H. Teranishi, Y. Yoshida, and M. Kojima, "Molecular forms of hypothalamic ghrelin and its regulation by fasting and 2-deoxy-d-glucose administration," Endocrinology, vol. 146, no. 6, pp. 2510-2516, 2005.

[55] M. F. Sonmez and E. Ozan, "Determination of ghrelin immunoreactivity in the rat stomach after fasting and refeeding," Acta Histochemica, vol. 109, no. 3, pp. 193-199, 2007.

[56] N. Govoni, R. De Iasio, C. Cocco, et al., "Gastric immunolocalization and plasma profiles of acyl-ghrelin in fasted and fastedrefed prepuberal gilts," Journal of Endocrinology, vol. 186, no. 3, pp. 505-513, 2005.

[57] H. Hosoda and K. Kangawa, "The autonomic nervous system regulates gastric ghrelin secretion in rats," Regulatory Peptides, vol. 146, no. 1-3, pp. 12-18, 2008.

[58] L. Soriano-Guillén, V. Barrios, G. Martos, J. A. Chowen, A. Campos-Barros, and J. Argente, "Effect of oral glucose administration on ghrelin levels in obese children," European Journal of Endocrinology, vol. 151, no. 1, pp. 119-121, 2004.

[59] F. Broglio, C. Gottero, F. Prodam, et al., "Ghrelin secretion is inhibited by glucose load and insulin-induced hypoglycaemia but unaffected by glucagon and arginine in humans," Clinical Endocrinology, vol. 61, no. 4, pp. 503-509, 2004.

[60] Y. Nakai, H. Hosoda, K. Nin, et al., "Plasma levels of active form of ghrelin during oral glucose tolerance test in patients with anorexia nervosa," European Journal of Endocrinology, vol. 149, no. 1, pp. R1-R3, 2003.

[61] T. Shiiya, M. Nakazato, M. Mizuta, et al., "Plasma ghrelin levels in lean and obese humans and the effect of glucose on ghrelin secretion," Journal of Clinical Endocrinology and Metabolism, vol. 87, no. 1, pp. 240-244, 2002.

[62] D. L. Williams, D. E. Cummings, H. J. Grill, and J. M. Kaplan, "Meal-related ghrelin suppression requires postgastric feedback," Endocrinology, vol. 144, no. 7, pp. 2765-2767, 2003.

[63] J. Overduin, R. S. Frayo, H. J. Grill, J. M. Kaplan, and D. E. Cummings, "Role of the duodenum and macronutrient type in ghrelin regulation," Endocrinology, vol. 146, no. 2, pp. 845850, 2004.

[64] L. C. Gormsen, J. Gjedsted, S. Gjedde, et al., "Free fatty acids decrease circulating ghrelin concentrations in humans," European Journal of Endocrinology, vol. 154, no. 5, pp. 667673, 2006.

[65] K. E. Foster-Schubert, J. Overduin, C. E. Prudom, et al., "Acyl and total ghrelin are suppressed strongly by ingested proteins, 
weakly by lipids, and biphasically by carbohydrates," Journal of Clinical Endocrinology and Metabolism, vol. 93, no. 5, pp. 1971-1979, 2008.

[66] M. Shimada, Y. Date, M. S. Mondal, et al., "Somatostatin suppresses ghrelin secretion from the rat stomach," Biochemical and Biophysical Research Communications, vol. 302, no. 3, pp. 520-525, 2003.

[67] T. M.-M. Tan, M. Vanderpump, B. Khoo, M. Patterson, M. A. Ghatei, and A. P. Goldstone, "Somatostatin infusion lowers plasma ghrelin without reducing appetite in adults with Prader-Willi syndrome," Journal of Clinical Endocrinology and Metabolism, vol. 89, no. 8, pp. 4162-4165, 2004.

[68] F. Broglio, P. Van Koetsveld, A. Benso, et al., "Ghrelin secretion is inhibited by either somatostatin or cortistatin in humans," Journal of Clinical Endocrinology and Metabolism, vol. 87, no. 10, pp. 4829-4832, 2002.

[69] C. D. de la Cour, P. Norlén, and R. Håkanson, "Secretion of ghrelin from rat stomach ghrelin cells in response to local microinfusion of candidate messenger compounds: a microdialysis study," Regulatory Peptides, vol. 143, no. 1-3, pp. 118-126, 2007.

[70] J. Kamegai, H. Tamura, T. Shimizu, S. Ishii, H. Sugihara, and S. Oikawa, "Effects of insulin, leptin, and glucagon on ghrelin secretion from isolated perfused rat stomach," Regulatory Peptides, vol. 119, no. 1-2, pp. 77-81, 2004.

[71] T. Katayama, S. Shimamoto, H. Oda, K. Nakahara, K. Kangawa, and N. Murakami, "Glucagon receptor expression and glucagon stimulation of ghrelin secretion in rat stomach," Biochemical and Biophysical Research Communications, vol. 357, no. 4, pp. 865-870, 2007.

[72] R. C. Paulo, R. Brundage, M. Cosma, K. L. Mielke, C. Y. Bowers, and J. D. Veldhuis, "Estrogen elevates the peak overnight production rate of acylated ghrelin," Journal of Clinical Endocrinology and Metabolism, vol. 93, no. 11, pp. 4440-4447, 2008.

[73] P. Kok, R. C. Paulo, M. Cosma, et al., "Estrogen supplementation selectively enhances hypothalamo-pituitary sensitivity to ghrelin in postmenopausal women," Journal of Clinical Endocrinology and Metabolism, vol. 93, no. 10, pp. 4020-4026, 2008.

[74] E. Kellokoski, S. M. Poykko, A. H. Karjalainen, et al., "Estrogen replacement therapy increases plasma ghrelin levels," Journal of Clinical Endocrinology and Metabolism, vol. 90, no. 5, pp. 2954-2963, 2005.

[75] S. Grinspoon, K. K. Miller, D. B. Herzog, K. A. Grieco, and A. Klibanski, "Effects of estrogen and recombinant human insulin-like growth factor-I on ghrelin secretion in severe undernutrition," Journal of Clinical Endocrinology and Metabolism, vol. 89, no. 8, pp. 3988-3993, 2004.

[76] M. Matsubara, I. Sakata, R. Wada, M. Yamazaki, K. Inoue, and T. Sakai, "Estrogen modulates ghrelin expression in the female rat stomach," Peptides, vol. 25, no. 2, pp. 289-297, 2004.

[77] I. Sakata, T. Tanaka, M. Yamazaki, T. Tanizaki, Z. Zheng, and T. Sakai, "Gastric estrogen directly induces ghrelin expression and production in the rat stomach," Journal of Endocrinology, vol. 190, no. 3, pp. 749-757, 2006.

[78] Z. Zhao, I. Sakata, Y. Okubo, K. Koike, K. Kangawa, and T. Sakai, "Gastric leptin, but not estrogen and somatostatin, contributes to the elevation of ghrelin mRNA expression level in fasted rats," Journal of Endocrinology, vol. 196, no. 3, pp. 529-538, 2008.

[79] A. Inui, "Acyl and desacyl ghrelin in anorexia nervosa," Psychoneuroendocrinology, vol. 30, no. 1, p. 115, 2005.
[80] A. Majuri, M. Santaniemi, K. Rautio, et al., "Rosiglitazone treatment increases plasma levels of adiponectin and decreases levels of resistin in overweight women with PCOS: a randomized placebo-controlled study," European Journal of Endocrinology, vol. 156, no. 2, pp. 263-269, 2007.

[81] D. Glintborg, M. Andersen, C. Hagen, et al., "Evaluation of metabolic risk markers in polycystic ovary syndrome (PCOS). Adiponectin, ghrelin, leptin and body composition in hirsute PCOS patients and controls," European Journal of Endocrinology, vol. 155, no. 2, pp. 337-345, 2006.

[82] E. Capristo, S. Farnetti, G. Mingrone, et al., "Reduced plasma ghrelin concentration in celiac disease after gluten-free diet treatment," Scandinavian Journal of Gastroenterology, vol. 40, no. 4, pp. 430-436, 2005.

[83] A. Rocco, G. Sarnelli, D. Compare, et al., "Tissue ghrelin level and gastric emptying rate in adult patients with celiac disease," Neurogastroenterology and Motility, vol. 20, no. 8, pp. 884-890, 2008.

[84] A. M. Haqq, S. C. Grambow, M. Muehlbauer, et al., "Ghrelin concentrations in Prader-Willi syndrome (PWS) infants and children: changes during development," Clinical Endocrinology, vol. 69, no. 6, pp. 911-920, 2008.

[85] A. Tatsuguchi, K. Miyake, K. Gudis, et al., "Effect of Helicobacter pylori infection on ghrelin expression in human gastric mucosa," American Journal of Gastroenterology, vol. 99, no. 11, pp. 2121-2127, 2004.

[86] H. Osawa, H. Kita, H. Ohnishi, et al., "Changes in plasma ghrelin levels, gastric ghrelin production, and body weight after Helicobacter pylori cure," Journal of Gastroenterology, vol. 41, no. 10, pp. 954-961, 2006.

[87] A. Shiotani, T. Miyanishi, N. Uedo, and H. Iishi, "Helicobacter pylori infection is associated with reduced circulating ghrelin levels independent of body mass index," Helicobacter, vol. 10, no. 5, pp. 373-378, 2005.

[88] H. Osawa, "Ghrelin and Helicobacter pylori infection," World Journal of Gastroenterology, vol. 14, no. 41, pp. 6327-6333, 2008.

[89] H. Suzuki, T. Masaoka, H. Hasoda, et al., "Helicobocter pylori infection modifies gastric and plasma ghrelin dynamics in Mongolian gerbils," Gut, vol. 53, no. 2, pp. 187-194, 2004.

[90] B. Neu, P. Randlkofer, M. Neuhofer, et al., "Helicobocter pylori induces apoptosis of rat gastric parietal cells," American Journal of Physiology, vol. 283, no. 2, pp. G309-G318, 2002.

[91] Y. Murayama, J. Miyagawa, Y. Shinomura, et al., "Morphological and functional restoration of parietal cells in Helicobacter pylori associated enlarged fold gastritis after eradication," Gut, vol. 45, no. 5, pp. 653-661, 1999. 

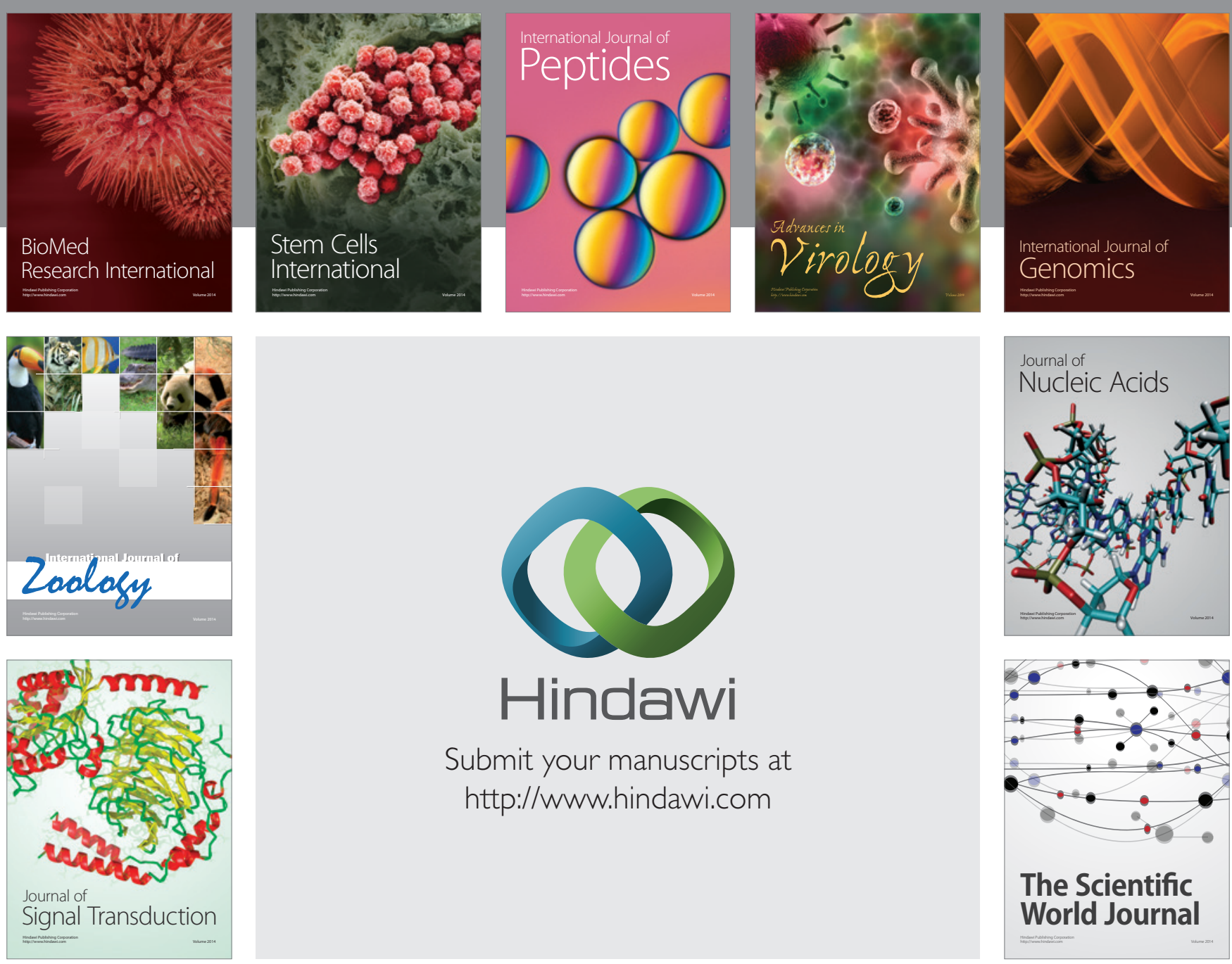

Submit your manuscripts at

http://www.hindawi.com
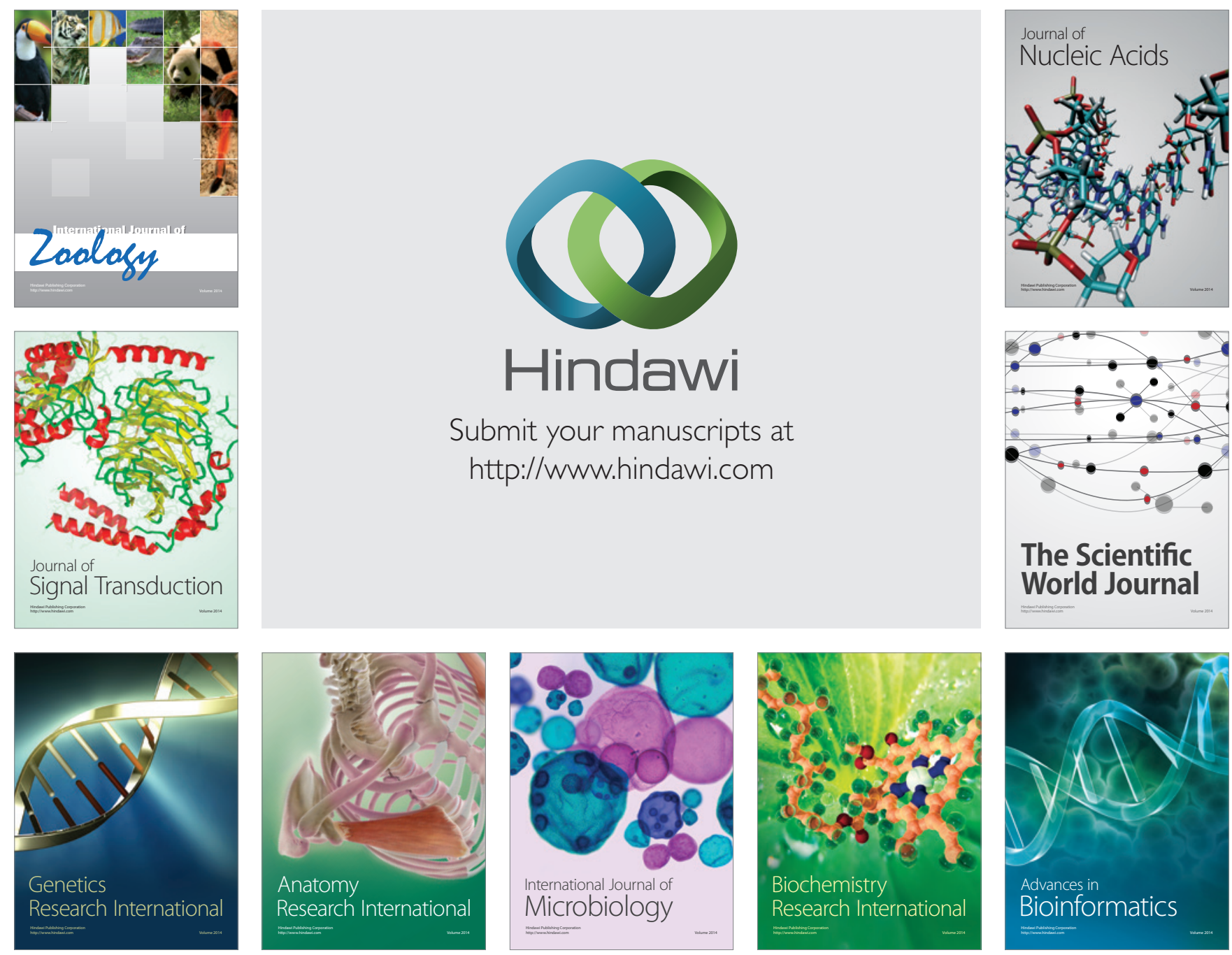

The Scientific World Journal
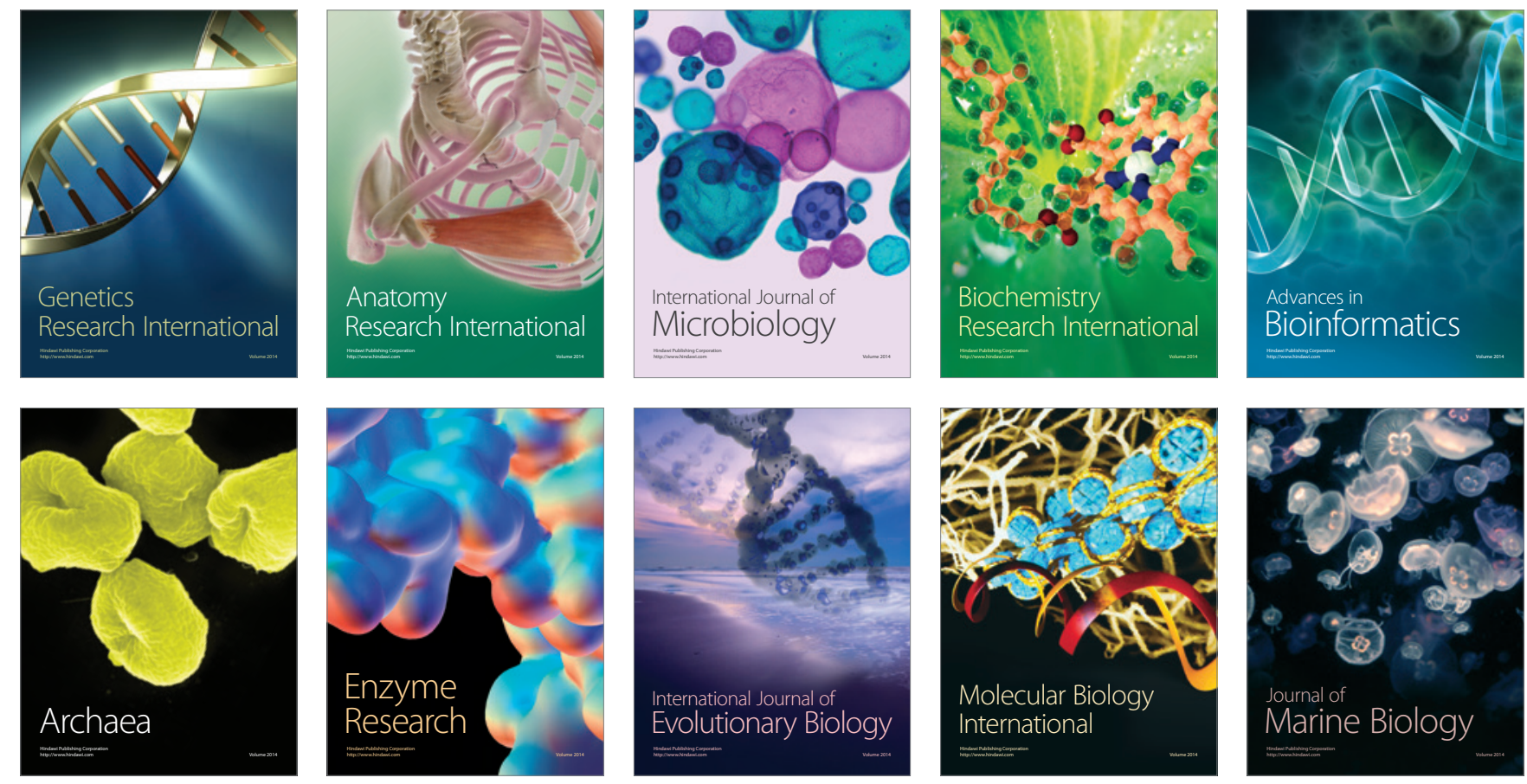